\title{
APPLICATION OF PACKAGING AND LABEL FOR MEMBERS OF PKK BUSINESS GROUP, COGREK VILLAGE, PARUNG DISTRICT
}

\author{
Levyda Levyda ${ }^{1}$, Kania Ratnasari ${ }^{*}$, Susy Bhudiharty ${ }^{1}$ \\ ${ }^{1}$ faculty of Economics, Sahid University \\ *kania.ratnasari@yahoo.com
}

\begin{abstract}
Science and Technology for the Community is carried out for business groups belonging to the PKK of Cogrek Village, Parung District. The group produces processed food with catfish raw material. After 1 (one) year of trying, it still has not experienced significant development. The main cause is a limited market, packaging and also labeling of catfish processed products that are less attractive. In order to increase market attractiveness, packaging and labels will be made for the group and marketing consultations. At present there is an increase in packaging aesthetic quality and labels
\end{abstract}

Keywords: Catfish Processed Products, Cogreg Village, Community Service, Label, Packaging

\section{INTRODUCTION}

Bogor Regency is one of 197 districts or cities that are designated as minapolitan areas by the Ministry of Maritime Affairs and Fisheries (KKP). Based on Bogor Regent Decree No.523.31 / 227 / Kpts / Huk / 2010 that there were four sub-districts selected as minapolitan areas, namely Ciseeng, Parung, Gunung Sindur, and Kemang Districts as catfish cultivation areas.Ciseeng sub-district as a minapolitan area has catfish culture spread in ten villages, Babakan, Putatnutug, Cibeuteung Udik, Cibeuteung Muara, ParigiMekar, Ciseeng, Cihowe, Cibentang, Karihkil and Kuripan.This partner of science and technology activities for the community ( $\mathrm{IbM}$ ) is a business group member of the PKK of Cogrek Village, Ciseeng Village, Parung Subdistrict. This PKK group is located at Perum BPP C2 / 15 RT. 06/07 Ds. Cogrek, Kec. Parung. The PKK group consists of 8 (eight) people who work together to produce and market the results of catfish-based food products. This catfish is obtained from the environment around the village of Cogrek.

At present, the home industry is producing processed fish, with various kinds of processed fish products that are developing in the village of Ciseeng. All processed fish products were produced by Mrs. Rasmi as a group leader. However, business development is still lacking, especially in terms of marketing. Label is a simple display on the product or intricately designed images that are one with packaging. Labels can only include brands or information (Kotler, 2000). The absence of packaging and labeling causes the amount of production cannot be maximized. According to Marinus (2002), the label is a part of a product that carries verbal information about the product or the seller. Kotler and Amstrong (2012) define that "packaging involves designing and producing the container or wrapper for a product" which means that the packaging process involves designing and producing, the main function of the packaging itself is to protect the product so that the product is maintained. Good packaging can build brand equity and drive sales. Packaging is the first part of the product that buyers face and is able to attract or get rid of buyers. The packaging of a product is usually carried out by producers to be able to seize consumer interest in purchasing goods. Producers try to give a good impression on their product packaging and create a new packaging model that is different from other manufacturers that produce similar products in the same market (Rangkuti, 2005) while Tjiptono (2011) states that the packaging of products has several objectives, namely (a) protection of contents (protection); (b) provide ease of use (operation); (c) useful in reusable; (d) provide promotion in the form of artistic aspects, colors, shapes and designs; (e) as one product identity (image); (f) facilitate the distribution process; and (g) can provide information (labeling) concerning the content, usage, quality, and as a reflection of product 
innovation related to technological progress and recycling. Like micro entrepreneurs in general, it cannot be separated from disturbing problems such as raw materials, marketing, finance and business management problems. They are a variety of problems that interfere with the sustainability of their business. So that technical guidance is needed so that the business still exists and helps the family economy.

Since the beginning of the business, this business group occupied the location in Perum. BPP C2 / 15 RT. 06/07, Ds. Cogrek, Kec. Parung. Processed catfish products are a type of food source of animal protein that is widely consumed by the community. Products made are Otak-otak, Dimsum, Meatballs (Bakso), Nugget, Bakso Tahu, Kerupuk Kulit and Kerupuk Tulang. Generally, they were made with conditions that are already good but business experience is still limited so marketing is still limited, and cannot be produced in large quantities. The meaning of production infrastructure for processing fish are still using mixers whose tamping power is only 2 (two) kilograms while each time the production process uses a standard amount of 50 (fifty) kilograms of fish. So that, the time of the production process becomes longer. The durable refractory product must have a large enough cooling capacity.

In addition to production activities, marketing of this fish is also carried out independently by groups of entrepreneurs. Marketing is still done among friends or relatives of business groups. The selling price of the product is relatively lower compared to the market price. This price is done so that the interest of buyers is higher, but cuts the profits of entrepreneurs. The thing that distinguishes this product from other products is not using preservatives and causes of taste. But this causes the product to be durable and mass-produced. So the distribution of products is limited. A breakthrough is needed so that production can be increased and distributed widely. Business people do very simple business based on the principle of family. This is indeed a characteristic of micro businesses in general, business owners act directly as workers both in the aspects of production and marketing aspects. The number of business working days is 30 days / month, meaning that this business does not know holidays. Business actors work according to routines, namely the purchase of catfish, spinning, milling, seeding, removal of materials according to the type of product, steaming, and packing. Limited equipment, the production process is usually done together after each mother's housework is finished.

The equipment used together is a mixer, and steaming. The processing process generally depends on the marketing time they choose. When marketing their products early in the morning, they will also soon get a package when processing early. Business people sell their own products. In conducting business, business actors make financial records. The profit and loss calculation of the business is carried out simply, namely revenue (the total price of the product produced) minus expenditure (the price of raw materials, and packaging. The difference between revenue and expenditure with a simple calculation is considered as profit, without taking into account the cost of labor themselves. Problem identification takes precedence over problems to address the need to improve the socio-economic conditions of business people. The approach taken is by increasing marketing capacity which is expected to increase production capacity. Increased production capacity will involve many factors, including expanding market segments. Expansion of market segments can be done through increased sales of processed catfish. For one year, the partners tried to market their products. These identification steps are also intended to be able to determine priorities in carrying out activities, so that mistakes in acting can be minimized. This identification process is carried out by means of a literature study to obtain information on the partner's environmental conditions and active interviews conducted between the implementing team and the crafting partners. This initial interview is to identify problems and possible solutions that might be implemented. Until now, this business group only focuses on fresh products that do not use preservatives and flavorings. This is because marketing is only done by word of mouth. This condition resulted in this business group having difficulty increasing its production volume. This has resulted in the group trying not to benefit from the economic benefits of the business they run. The problem faced by these business actors is that their business activities are micro businesses with limited business capacity due to limited market capacity. For this reason, these entrepreneurs hope for market development, with the hope that their welfare will increase. In marketing activities, the types of processed products to be tested will be packaged and labeled attractive. By prioritizing this, it is expected that consumers will be more interested in buying, which in turn is expected to increase the production volume of catfish. 


\section{METHOD}

In general, the output targets to be achieved in this activity plan for business actors are (1) marketing management, and (2) making packaging and labels. The target can be specified as follows that the business group gets its main types of training / mentoring for (a) Marketing improvements: packaging design and labels (b) Organizing improvement.

Based on the problems previously described and the agreement between the proposer team and partners, the solutions offered to overcome the existing problems can be done using the following approach methods such as (1) The process of building resource motivation. This process is intended so that the resources to be empowered have a desire to advance business through increasing business capacity. The existence of active participation will have an impact on improving their welfare (2) Increased business capacity. The process of increasing business capacity will have an impact on the welfare of micro businesses that have been cultivated for a long time but have not provided meaningful welfare. Business capacity building is carried out by increasing marketing capabilities. The marketing development program that will be carried out is to improve the label and market design, to attract consumers (3) Mentoring process. To maintain commitment, the sustainability of the program and build good teamwork, the mentoring process will be carried out (4) Sustainability. This program is not an instant activity so the sustainability of the program becomes a joint commitment between proposers through the Sahid Jakarta University LPPM and craftsmen partners in the Cogrek Village area of Parung Subdistrict.

\section{RESULT AND DISCUSSION}

The implementation of this activity begins with the coordinating team of the team with partners, namely the group of entrepreneurs, the Cogreg BPP company. The purpose of coordination is that the implementation of activities can run efficiently and effectively. In coordination activities, the activity schedule and activity objectives are delivered. After an agreement has been made between the abdimas team and partners, a site visit is conducted. Activities carried out at the activities location are (1) Introduction of the community development team and partners, (2) Business presentation by partner, (3) Observation of products and business activities by the community development team, (4) Presentation of proposals from the community development team

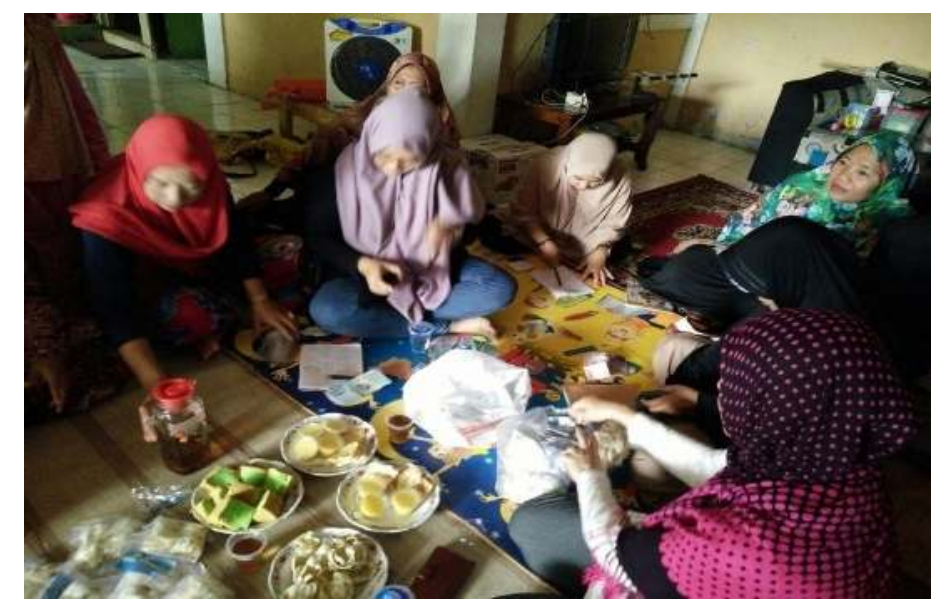

Figure1. The Activity Partner

From business presentations and problems, information is obtained are: (1) Products without preservatives so they don't last long, (2) The storage capacity of the final product is very limited, (3) One type of packaging and label is used for all types of products. From the observation results obtained 
the following information such as: (1) Less attractive packaging (2) The label is blue, less bright, (3) There is no halal label.

The presentation of proposals from the activity team is as follows: (1) Packaging has a very strategic role because packaging is a container or packaging for food products. The market is very important to maintain the quality and safety of food and increase attractiveness. Another role is to protect food ingredients to avoid things that can cause physical, chemical and mechanical damage. Packaging can be classified in various ways. Based on the frequency of its use, packaging is classified as a disposable packaging, packaging that can be used repeatedly (multitrip), a package that can no longer be used but can be used for other purposes. Based on the ability to protect its products, packaging is classified as hermetic packaging, which is a package that is perfectly impassable by gas, air and water vapor so that the product is bacterial resistant, light-resistant packaging is a non-transparent packaging that does not damage fat and vitamins, high temperature resistant packaging namely packaging for products that need heating or pasteurization. (2) From the results of observations and discussions with partners, it can be concluded that the cracker packaging currently used is a plastic disposable packaging with a size of $20 \mathrm{X} 30 \mathrm{CmX} 0.010$. Partners do not use super stand up plastic. Packaging for dim sum and tofu meatballs is used in plastic size $1 / 2 \mathrm{Kg}$.

All types of products use the same packaging. This packaging is sufficient for crackers. Some products such as meatballs, meatball tofu and dimsum are products that contain water so that they are easily contaminated with bacteria and are not durable, so it is recommended to use disposable and hermatic packaging. (3) Partners are aware of the weakness of their packaging so they only produce in limited quantities. This condition causes limited production volume. (4) From the aesthetic aspect, the packaging used by partners is classified as not simple. The reason for using the packaging is to reduce costs. It is recommended that you use a more attractive package because the packaging also functions as a promotional tool. (5) Presentation about the Label as follows that the label serves as a brand name carrier media, media delivery of information about who makes the product, where the product is made, when it is made, raw materials used, processing methods, storage methods, safe use methods. Labels need to be updated to avoid being outdated. Labels can be made concisely with graphic technology. (6) From the results of observations and interviews, partners have used labels. Partner label color is blue. The information available on the label is the brand name namely Lele Q and the type of product namely nugget, dimsum, meatballs, tofu meatballs, otak-otak, skin crackers, bone crackers. This type of product is provided so that partners can save label costs. Giving product type identity is done manually. So, it's not interesting at all. (7) The abdimas team recommends that the label design be adjusted to the times, labels in the form of stickers that can be attached to the packaging.

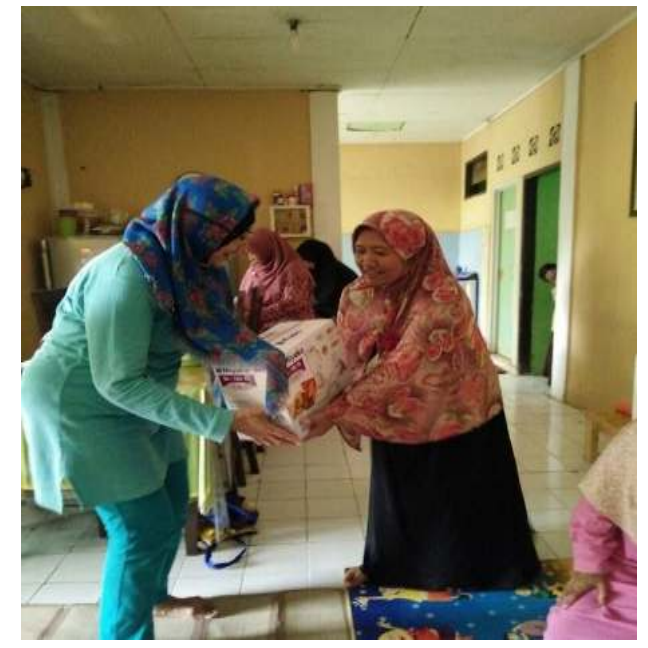

Figure 2. Giving souvenirs to Partners

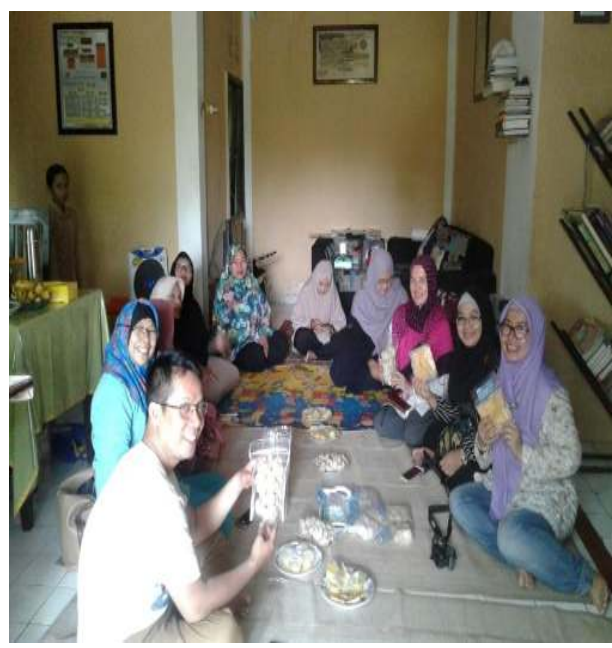

Figure 3. Dialogue Team and Partners 


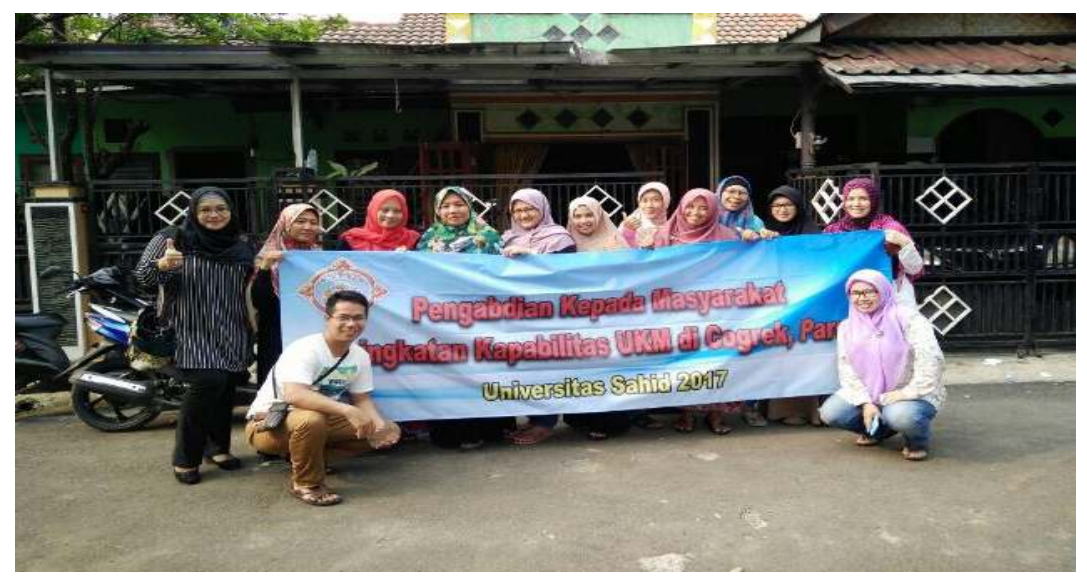

Figure 4. Team and Partners

The following below are some photos of processed catfish products produced by Ciseeng village partners before and after the community service activities provided by the team. Significantly changes in the packaging and label of catfish processed products.

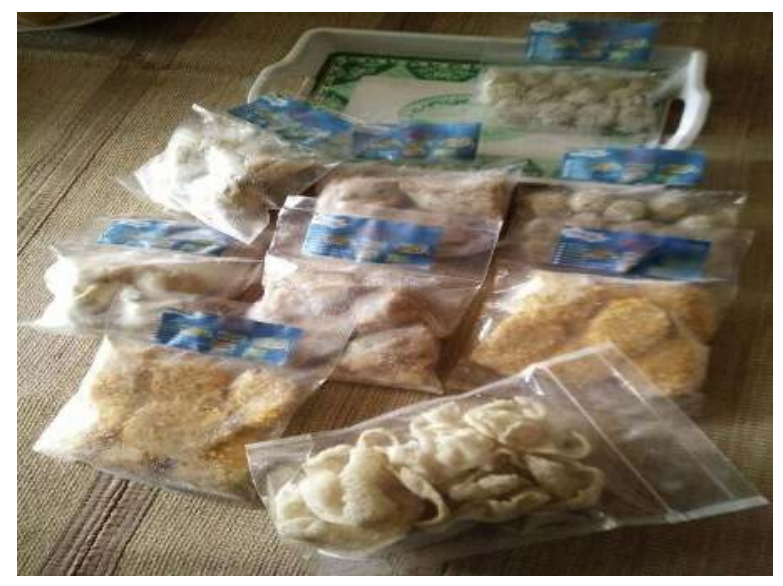

Figure 5. Old packaging and labels for various catfish processed products
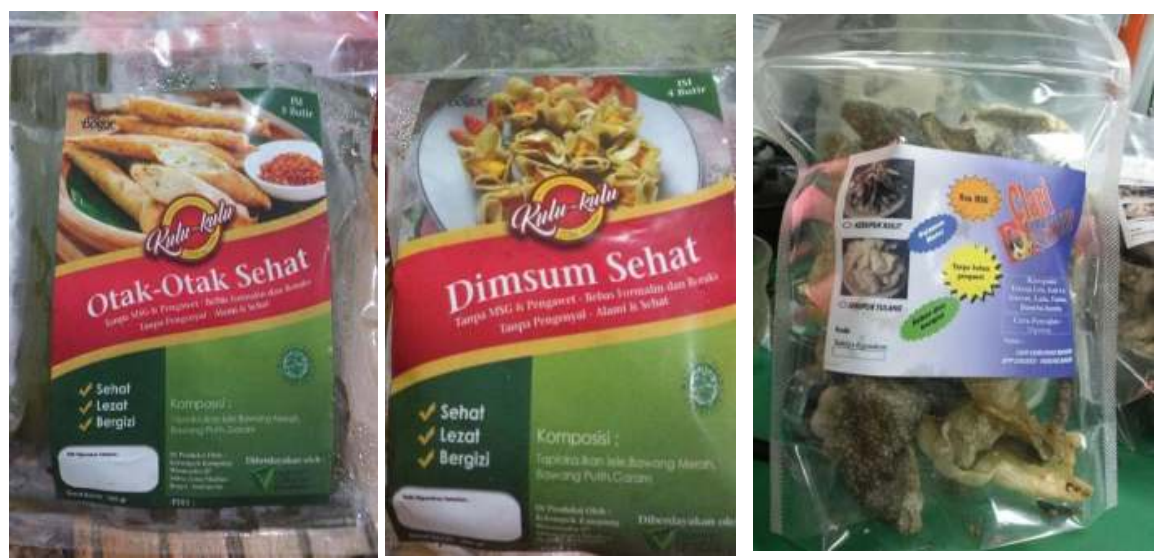

Figure 6. New packaging and labels for Dimsum, Otak-otak and crackers 


\section{CONCLUSION}

Currently, the mitra has made repairs in the packaging, so that the purpose of this activity is achieved. The mitraof this activity has made a new package that includes information as follows: (1) Brand name, (2) The composition of the material used, (3) Manufacturer Name, (4) Fill weight, (5) Halal label. The partners have also made different packages for each type of product while the current partner packaging is already explained before. The conclusion of these activities is that partners need counseling about security and labels to increase the attractiveness of their products. Currently packaging is still needed from the aspect of food quality.

\section{REFERENCES}

Kotler, P. (2000). Manajemen Pemasaran. Edisi 2 h. 477. Jakarta: Prenhallindo.

Kotler, P., \& Armstrong, G. (2008). Prinsip-prinsip Pemasaran (judul asli: Principles of Marketing), edisi kedua belas, jilid 1. Penerjemah Bob Sabran. Jakarta: Erlangga.

Marius, P.A. (2002). Dasar-dasar Pemasaran. Jakarta: PT Raja Grafindo Persada.

Peraturan Menteri Kelautan dan Perikanan Republik Indonesia Nomor 39/Permen - KP/2014 Tentang Rencana Kerja Kementrian Kelautan dan Perikanan Tahun 2015. Kelautan dan Perikanan Dalam Angka 2013.

Rangkuti, F. (1998). Analisis SWOT teknik membedah kasus bisnis. Gramedia Pustaka Utama..

Tjiptono, F., \& Chandra, G. (2005). Service, quality \& satisfaction. Yogyakarta: Andi Offset. 